\title{
Household Role in Coping with Precarious Work. Evidence from Qualitative Research in Urban Romania and Switzerland
}

\section{Ana Maria D. Preoteasa ${ }^{1}{ }^{*}$, Rebekka Sieber $^{2,3}$, Monica Budowski' $^{2,}$ and Christian Suter ${ }^{3}$}

${ }^{1}$ Romanian Academy, Research Institute for Quality of Life, 13 Calea 13 Septembrie, 050711 - Bucharest, Romania. 2 University of Fribourg, Division of Sociology, Social Policy and Social Work, Rte des Bonnesfontaines 11, CH1700 Freiburg, Switzerland.

${ }^{3}$ University of Neuchâtel, Institute of Sociology, Faubourg de l'Hôpital 27, 2000 Neuchâtel, Switzerland.

KEYWORDS

Household

Precarious work

Romania

Switzerland

\section{A BSTRACT}

This paper presents the results of a qualitative comparative study that looked at the meaning of 'precarious work' in households situated in the position of 'precarious prosperity' in Switzerland and Romania in 2013. The aim of this research is to explore the experiences of individuals with precarious work and to embed them into their household and national structural contexts. Employment patterns in the two countries are similar in terms of uncertainty and instability, yet vary in many other aspects. While in Romania insecurity is due mainly to the very low incomes, in Switzerland it stems from nonstandard contracts. The research shows that for households of precarious prosperity, precarious work is both a strategy to cope with uncertainty and instability and a circumstance leading to precariousness. The analysis explores qualitatively the meaning that individuals living in households of precarious prosperity attribute to their employment situation as contextualized by the interplay between household and individual situation.

\footnotetext{
*Contact address: anita@iccv.ro, preoteasaanita@yahoo.com (A.M. Preoteasa).
} 


\section{Introduction}

The current debate on the meaning of work in modern societies is divided between work as a means of physical survival and work as a means of social identity (Ardichvili and Kuchinke 2009; Doherty 2009; Foster 2012). Even before the economic crisis, the increasing flexibility of labour markets has led to important changes for working life and consequently for the individual worker's life-course. The increase of non-standard arrangements resulted in the transferring of risks to employers and their families (Standing 2011). In developed countries, the key dimensions of precarious work are associated with wage discrepancies in comparison to standard employment and could lead to inequality (Kalleberg 2009). In post-socialist societies and other less developed countries 'precarious work is often the norm and is linked more to the informal than the formal economy and to whether jobs pay above poverty wages' (Kalleberg 2009, 15). A qualitative study on the evaluation of precarious employment in Germany points to the subjective aspect of precarious work definition. Having employee rights and the meaningfulness of work influence whether work is considered precarious or not (Gefken et al. 2015). Paugam (2000) distinguishes between precarious jobs ('précarité de l'emploi') and precarious work ('précarité du travail'). Precarious jobs refer to objective working and employment conditions, while precarious work is about the individual perception of being detached or deintegrated from work (Paugam 2000).

This paper's aim is to explore the precarious work of individuals living in households in precarious prosperity, and to analyse the multiple facets of work and the individuals' evaluation of their work situation. Precarious prosperity is understood as a household welfare position in-between poverty and secure prosperity (Budowski et al. 2010). We compare two countries that differ strongly with respect to standards of living and opportunity structures. They are very different in regards to their historical paths: Switzerland has a stable economy whereas Romania is transitioning from a socialist to a market economy. Today, both countries are subject to the consequences of the global liberalization of labour markets, referring to 
the process whereby the private sector dominates the government sector through the control and regulation of the labour market. The concept of precarious work is defined in contrast to secure work and decent work.

The originality of the article consists in a complex approach of precarious work. The individual experience of precarious work is shaped by the resources of each household and the opportunity structures within each country. Opportunity structures refer to the opportunities provided by the specific interplay between the different domains of the welfare regime: work, state, communities, and households. We focus on the comparison of the meanings given to the experience of precarious work in the two countries previously mentioned. It encompasses the definition and description of precarious job characteristics and adds the subjective perspective of people having a precarious job. Therefore, the article contributes to the literature by considering the family-relatedness of precarious work approach (Greenhaus and Powell 2012) in two very different contexts: Romania and Switzerland. Our qualitative research enabled us to study the dual role of family in precarious work situation. The analysis is deepened by embedding precarious work into the household context, and contributes to the broader understanding of the complex process of employment decisions, and the mechanisms involved in constructing the experience of precarious jobs. Considering households with comparable economic levels (precarious prosperity) in both countries and more than that looking at individuals with similar working situations (precarious work) we had the chance to investigate how the family influences relations with work. The individuals are impoverished by the scarce household economic situation and their responsibilities in extended family. These situations offered the opportunity to see how the family environment could be a buffer in coping with a precarious work situation or how the precarious economic condition of the household could contribute to the increased risk. 


\section{Theoretical framework}

\section{Precarious work concept}

Precarious work was theoretically operationalized starting from the main characteristics included in a majority of the definitions (Kalleberg 2009; Leschke 2009; Vosko 2003). The meaning of the concept differs from country to country. Whether the type of work contract is important to the definition of precarious work is debatable. Some scholars consider the non-standard contract a main dimension of precarious work, while Vosko $(2010,2)$ argues that 'some non-standard employment is relatively secure and some full-time permanent employment is precarious. Precariousness can cut across all kinds of work for remuneration'. Other definitions (Walker and Marti 2010) delineate insecurity in terms of future, economic, and social protection as the characteristics circumscribing precarious work.

Precarious work entails a broadly disbursed social burden, although it directly diminishes individual's wellbeing as well as their and household's regardless of the general level of the standard of living in a country. Scholars have demonstrated that precarious work has important consequences at the macroeconomic, community, family, and individual levels. The main consequence at the economic and social level is the increase of inequality (Kalleberg 2009). At the individual level, studies are not conclusive. More studies have highlighted that precarious work has negative consequences for health effects (Sverke et al. 2002; Witte 1999), as does employment insecurity, uncertainty, and the lack of career stability (Wallace et al., 2007; Zeytinoglu and Cooke 2008). Job uncertainty is related to the impossibility of making long-term plans, postpones life transitions (toward independent life, family or relationship starting) (Coontz 2005; Dewilde and Lancee 2013; Dewilde 2003; Umney and Kretsos 2015) and delays fertility plans (Hanappi et al. 2012, 2014).

Whereas the bulk of research on precarious work has focused on working conditions, employment relationships or conditions on the labour market that generate precarious work, very little research has been 
dedicated to what precarious work means for individuals in households living in insecure socioeconomic conditions, that is, in precarious prosperity. Research has rarely looked qualitatively at the connection between individuals embedded in their household and the households' resources and constraints when pursuing work or entering work relationships. Households in precarious prosperity are generally not the target of social policies and therefore particularly rely on the opportunities that the households, their communities, the labour market, or the state provide. Kraemer (2008), one of the scholars investigating the different facets of precarious work, identifies the positive aspects precarious work can have: it is still better than unemployment and may be understood as a transitory situation that has the chance to be transformed into stable work. Whether the more positive or negative aspects are perceived depends on an individual's opportunities, his or her confidence in expected opportunities and position in the life-course. In addition, the perception of precarious work depends upon the household members' resources, their households' resources, the individuals' and households' evaluation of opportunities that the labour market provides, and the decommodification opportunities that the state provides (Budowski et al. 2015).

\section{Work-family relation}

The relationship between work and family was extensively studied and the empirical evidence confirmed that the various work decisions are influenced by family situation (Greenhaus and Powell 2012). For instance, the presence of children in a family could lead one partner to leave their job and transfer to the role of housewife (Lebert and Voorpostel 2016; Powell and Greenhaus 2010; Greenhaus and Foley 2007) or a switch to self-employment or homework based (Craig, Powell, and Cortis 2012). Also, the presence of an ill family member, in the absence of consistent social services support, could lead also cause one partner to leave work in order to take on the caretaker role. On the other hand, the life-course position implied different family roles and influence the work decision (Nilsen 2012). 
Two theories delineate the competing work and family roles: Conflict and Enrichment. The work-family conflict theory is referring to the interference between work and home life. The family roles require a large amount of individual resources and the traditional values creates a lot of pressure to offer high quality home care, caregiving, and education (Allen $e t$ al. 2013; Greenhaus and Foley 2007). Previous research showed that life satisfaction is strongly influenced by satisfaction with work and marriage (Perrone, Webb, and Jackson 2007). Also, an increased work-life balance leads to higher satisfaction (Hauw and Greenhaus 2014). The work family enrichment supposes that resources or positive affect acquired in one role enables them to become more effective and more satisfied in the other role (Greenhaus and Powell 2006; Greenhaus and Foley 2007) or 'where the values and activities of each domain benefited the other' (Marcus-Newhall et al. 2008, 197). The workplace flexibility (flextime or flexplace) reduces the work-family conflict by moderating the 'psychological and the physical boundaries that exist between work and family roles' (Allen et al. 2013).

The relation between family situation and various work decisions was theorized using the family-relatedness of work decision (FRWD) concept (Greenhaus and Powell 2012, 246) in order to 'capture diverse effects of family situations on decisions on work domain'. The FRWD analysis framework included also the individual, organizational, and societal factors/context and proposes a complex approach in work decision analysis.

\section{Methods}

The comparative analysis between the two countries follows the logic of a similarly designed methodology (Przeworski and Teune 1970) and the similarity of the population we want to examine, namely those in the welfare position of precarious prosperity. This corresponds to the 'strategic comparison' concept recommended by Ragin (1987) and Rihoux and Ragin (2009). The variation of structural contexts, diversity, is balanced with homogeneity using comparable socioeconomic groups, characterized by the 
same conditions of 'precarious prosperity'.

We employed a similar methodology in both countries: a purposive sampling procedure and a screening procedure in order to identify households living in precarious prosperity. The first step for the screening procedure was a probabilistic sampling: random route in Romania and random selection of telephone numbers in Switzerland. The second step consisted in applying a very similar screening questionnaire to select the households. The next step to ensure a valid comparison was to select households living in a similar and comparable relative welfare position. This means that we considered the country-specific differences in standard of living and relative welfare positions within each country. Inspired by Townsend's (2010) poverty definition, this identified the intermediate household welfare position of precarious prosperity by means of a financial and a deprivation threshold and their combination. Applying the multidimensional measurement of poverty (the intersection between material deprivation and income) we distinguish three different 'welfare positions': prosperity/non-poverty, precarious prosperity, and (consistent) poverty (Budowski et al. 2010; Precupetu et al. 2015).

Table 1: Criteria for the definition of the household welfare position 'precarious prosperity'

Romania

$60-100 \%$ of median equivalized

household income, OR

$>100 \%$ of median income and severely

deprived (4 or more deprivations)
Switzerland

$60-80 \%$ of the median equivalized household income, OR $<60 \%$ of the median income and not more than 1 deprivation, OR $>80 \%$ of the median income and 2 or more deprivations 
The interviews were conducted in 2013. In Switzerland (CH) fifty interviews were carried out in three urban areas (Bern, Lausanne, Zürich). In Romania (RO) fifty households were interviewed in both urban and rural areas. For reasons of comparability we retained only the urban cases (twenty-five) in Romania (Cluj-Napoca) for this article.

The guide for the qualitative interviews was similar for Romania and Switzerland and included retrospective, biographical information in addition to data about the present situation of the respondent and his household: employment, standard of living, dwelling, coping strategies. Employment was extensively looked at including the work contract, working conditions, work trajectory, attitudes and evolutions of work conditions, and perspectives. The face-to-face interviews were conducted with one or more members of the households. The main aim of the interview was to collect information about the household situation and at the same time about the individual situation of the respondent (employment history and actual situation, employment prospects). The interview duration was between 1 and 2 hours and all data were anonymized.

The cases for the analysis consisted of households having at least one household member with a precarious job; as we had at our disposal information collected from the other family members, it did not have to be the respondent who had a precarious job.

Table 2: Criteria in operationalizing precarious work

Objective Subjective

\begin{tabular}{lll}
\hline Uncertainty for future & Perceived uncertainty & $\sqrt{ }$ \\
& Temporary contract or informal & $\sqrt{ }$ \\
\hline Economic insecurity & $\begin{array}{l}\text { Wage variability } \\
\text { Low level of income - under 60\% } \\
\text { of national median wage }\end{array}$ & $\sqrt{ }$ \\
\hline $\begin{array}{l}\text { Insecurity for health } \\
\text { and social protection }\end{array}$ & $\begin{array}{l}\text { Absence or limited insurance } \\
\text { (informal, quasi-formal or } \\
\text { temporary contract) }\end{array}$ & $\sqrt{ }$ \\
&
\end{tabular}


A thematic analysis was employed applying both the theoretical framework and the inductive approach. The thematic (objective and subjective) framework categories included were similar for $\mathrm{RO}$ and $\mathrm{CH}$ : work characteristics, family life and structure, work-life balance. The analysis considered the interaction and interplay (Saldana 2011) between the framework categories and was conducted using MaxQda 11 software.

\section{Analysis and Results}

\section{Precarious jobs in relation with individual needs and desires}

We account for the experience of precarious work for the individuals in relation with different aspects of their lives and the household. In Romania, out of the urban sample, fourteen households we identified with at least one member having a precarious job. Thirteen out of the fifty households interviewed in Switzerland had at least one member in a precarious job.

Table 3: Romanian cases (E employed, O occasional work, $P$ permanent, PT parttime, $T$ - temporary)

\begin{tabular}{|c|c|c|c|c|c|c|c|c|}
\hline ID & Sex & $\begin{array}{l}\text { Year } \\
\text { of } \\
\text { birth }\end{array}$ & $\begin{array}{l}\text { Civil } \\
\text { status and family } \\
\text { situation }\end{array}$ & Education & Employment status \&occupation & Contract & $\begin{array}{l}\text { Wage level } \\
<\text { Wage } \\
\text { median }\end{array}$ & Variable \\
\hline RO_01 & $\mathrm{F}$ & 1969 & Unmarried, one child & Voccational school & E, janitor & P PT & $\sqrt{ }$ & \\
\hline RO_02 & $\mathrm{F}$ & 1958 & Married* & $\begin{array}{l}\text { Voccational school } \\
\text { Secondary school }(8\end{array}$ & E, skilled worker & $\mathrm{P}$ & $\sqrt{ }$ & \\
\hline RO_03 & $\mathrm{F}$ & 1980 & Unmarried, one child & grades ) & E, janitor & $\mathrm{P}$ & $\sqrt{ }$ & \\
\hline RO_05 & $\mathrm{F}$ & 1972 & Married, one child & High school Incomplete & E, skilled worker & $\mathrm{P}$ & $\sqrt{ }$ & \\
\hline RO_06 & $\mathrm{F}$ & 1986 & $\begin{array}{l}\text { Married, } 1 \text { child } \\
\text { Unmarried, lives in }\end{array}$ & University BA & E, merchandiser & $\mathrm{P}$ & $\sqrt{ }$ & \\
\hline RO_08 & $\mathrm{F}$ & 1991 & $\begin{array}{l}\text { extended } \mathrm{HH} \\
\text { Married, } 1 \text { child, lives }\end{array}$ & High school & E, electronics worker & $\mathrm{T}$ & $\sqrt{ }$ & $\sqrt{ }$ \\
\hline RO_09 & FM & 1976 & in extended $\mathrm{HH}$ & University BA & $\mathrm{O}$, masseur, bricoleur & No & $\sqrt{ }$ & \\
\hline RO_11 & $\mathrm{F}$ & 1959 & Married, one child & High school & E, personal assistant of disabled son & $\mathrm{P}$ & $\sqrt{ }$ & \\
\hline RO_12 & $\mathrm{F}$ & 1986 & $\begin{array}{l}\text { Unmarried, one child } \\
\text { Married, one child, }\end{array}$ & High school Incomplete & E, bartender & $\mathrm{P}$ & & \\
\hline RO_13 & MF & 1975 & lives in extended $\mathrm{HH}$ & Voccational school & E, fast-food worker & $\mathrm{P}$ & $\sqrt{ }$ & \\
\hline RO_18 & M & 1968 & Married, one child & High school Incomplete & E, stocker & $\mathrm{P}$ & $\sqrt{ }$ & $\sqrt{ }$ \\
\hline $\mathrm{RO}_{-}^{-} 21$ & $\mathrm{~F}$ & 1956 & Married & Vocational school & $\mathrm{O}$, babysitter/housekeeper & No & $\sqrt{ }$ & $\sqrt{ }$ \\
\hline RO_22 & $\mathrm{M}$ & 1961 & Married & MA & E, school teacher & $\mathrm{T}$ & $\sqrt{ }$ & \\
\hline RO_24 & $\mathrm{F}$ & 1984 & $\begin{array}{l}\text { Unmarried, lives in } \\
\text { couple }\end{array}$ & University BA & E, PhD student, & $\mathrm{T}$ & $\sqrt{ }$ & \\
\hline
\end{tabular}

*all married persons are living with husband/wife 
Table 4: Swiss cases (E employed, O occasional work, P permanent, PT part-time, $T$ - temporary, SLC service level contract, SE self-employed)

\begin{tabular}{|c|c|c|c|c|c|c|c|c|}
\hline ID & Sex & $\begin{array}{l}\text { Year } \\
\text { of } \\
\text { birth }\end{array}$ & Civil status and family situation & Education & $\begin{array}{l}\text { Employment status } \\
\text { \&occupation }\end{array}$ & $\begin{array}{l}\text { Working } \\
\text { contract }\end{array}$ & $\begin{array}{l}\text { Wage } \\
<\text { Wage } \\
\text { median }\end{array}$ & Variable \\
\hline $\mathrm{CH} 1$ & $\mathrm{~F}$ & 1969 & Unmarried, lives in couple & Professional education & $\mathrm{E}$, nurse & $\mathrm{P}, \mathrm{PT}$ & & $\sqrt{ }$ \\
\hline $\mathrm{CH} 3$ & M & 1957 & Divorced, lives in couple & University BA & $\mathrm{E}, \mathrm{SE}$, teacher & $\mathrm{P}, \mathrm{PT}$ & & $\sqrt{ }$ \\
\hline $\mathrm{CH} 4$ & $\mathrm{~F}$ & 1961 & Unmarried, lives alone & $\begin{array}{l}\text { Secondary school (12- } \\
\text { 13years) }\end{array}$ & E, journalist & SLC & $\sqrt{ }$ & $\sqrt{ }$ \\
\hline $\mathrm{CH} 17$ & $\mathrm{~F}$ & 1961 & Married, one child & Secondary school ( 9 years) & E, day nanny & $\mathrm{P}$ & $\sqrt{ }$ & \\
\hline $\mathrm{CH} 19$ & M & 1963 & Married, lives with wife & University & E, taxi driver & PS_E & & $\sqrt{ }$ \\
\hline $\mathrm{CH} 23$ & $\mathrm{~F}$ & 1967 & Married, one child & $\begin{array}{l}\text { Secondary school (12-13 } \\
\text { years) }\end{array}$ & E, cleaner & $\mathrm{T}$ & $\sqrt{ }$ & $\sqrt{ }$ \\
\hline $\mathrm{CH} 24$ & $\mathrm{~F}$ & 1982 & Married, one child & $\begin{array}{l}\text { Secondary school } \\
\text { incomplete }\end{array}$ & $\mathrm{O}$, hairdresser & No & & $\sqrt{ }$ \\
\hline $\mathrm{CH} 25$ & $\mathrm{~F}$ & 1964 & Married, three children in the $\mathrm{HH}$ & Primary school & E, sales representative & $\mathrm{T}, \mathrm{S}-\mathrm{E}$ & & $\sqrt{ }$ \\
\hline CH35 & $\mathrm{F}$ & 1959 & $\begin{array}{l}\text { Divorced, lone mother of two } \\
\text { children }\end{array}$ & Professional education & E, SE, podiatrist & $\mathrm{P}, \mathrm{PT}$ & & $\sqrt{ }$ \\
\hline $\mathrm{CH} 41$ & $\mathrm{~F}$ & 1981 & Single, lives with parents and brother & Primary school & O, cleaner & TA & $\sqrt{ }$ & \\
\hline $\mathrm{CH} 42$ & $\mathrm{~F}$ & 1950 & Married, lives with husband & Professional education & E, waiter & $\mathrm{P}$ & $\sqrt{ }$ & \\
\hline $\mathrm{CH} 43$ & M & 1954 & Divorced, lives alone & University & $\mathrm{O}$, actor & $\mathrm{T}$ & & $\sqrt{ }$ \\
\hline CH54 & $\mathrm{F}$ & 1965 & Unmarried, lives alone & University & E, SE, photographer & $\mathrm{P}, \mathrm{PT}$ & & $\sqrt{ }$ \\
\hline
\end{tabular}

Our analysis suggests that the work perceptions result from the interplay between individual aspirations, environment (family or community) and structural opportunities. People from both samples referred to their work with regards either to their individual identity or to their external constraints, such as the family and opportunities provided by the labour market. The comparison between the two countries revealed very different situations. While in Switzerland self-fulfilment was one of the major reasons for choosing a job, even if it was with low income, in Romania precarious jobs were basically considered as revenue and the discourses about working life referred to economic needs. Even if the working conditions were difficult, they did not want to resign:

Working conditions? I cannot tell you... It is very hot inside (a fastfood kitchen)... At the beginning, I sweated awfully... But I got used to it, you get used to that (RO13).

A strong personal satisfaction was related to the continuity of the same working place. Before 1990, in communist times, people rarely changed jobs. It occurred mainly for people moving to another locality. Individualization and the liberalization of labour markets has outdated the concept of the "job for life' concept (Fenton and Dermott 2006; Lloyd 2012; Procoli 2004). A 
Romanian man in the sample decided to change his career from a sales director to a masseur. He took this decision because of his deliberations on the structural changes in the labour market but also because he was not satisfied with his position as a sales manager: he did not like the way he was forced to shape the interaction with clients and the role he had to play to be successful (his 'personal performance,' Brown and Peterson 1994), as this contrasted with his personal ethic (Doherty 2009):

I'm tired of lying. Do you understand? Sales means lying generally to, uh, anything, even if you say 'uh, well man, you need this stuff' you have to convince him, to force him to buy from you, even if he knows he does not need it and so on. I do not want to do this, simply [....] when somebody comes to a massage, he comes with pleasure, (...) comes because he wants to feel good and I provide pleasure and do not offer him anything he does not need, I do not force him, he comes, because he has a need that I am able to meet, then, he, when client leaves me, leaves me happy (RO09).

The interviewee explained the change from being a sales manager to his new profession by the intrinsic work satisfaction his work provided and the correspondence with ethical values. Reorienting a career entails periods of insecurity and uncertainty of income: the interviewee has to build up his clientele.

The perceptions of a precarious job in the Swiss sample differed and also went beyond the objective situation (i.e. the working contract and conditions). One of them referred to the positive interaction with other people at the workplace:

It's good to meet people, to talk, because always at home [...] Well, you always have to do the housework, but it does well and I got to know new people and all that. I thought about working as a freelancer, to work at people's homes. I already have people coming to my home to have a haircut (CH24).

Another positive element was the possibility to work at home with flexible work hours. Some of the interviewees also mentioned other positive aspects of their working conditions: being free when working on call, having time to read when waiting in the taxi, being your own boss when working as 
self-employed:

I am very well. You have to work, work, you have to dedicate many hours [...] Days are long, because you have to wait a lot [...] But I am relatively autonomous, it's me who decides. For example, if I am tired or sick, or if I have a private appointment, I can do it without asking the permission of my boss. [...] I always say, the best as a taxi driver is while you're waiting for the customer. I can read many things, really. It's the only advantage (CH19).

Among the interviewees in liberal professions, there was the element of a professional choice: three persons in $\mathrm{CH}$ chose a profession for selffulfilment, even though they knew that the employment prospects were difficult. The element of choice was also important for the self-employed: they take the risk of insecurity for doing something they like (Umney and Kretsos 2015):

Quite a lot has happened concerning my work. I was employed by Keystone during 15 years and I decided to resign from my contract in March, so now I am really independent [...] I try to fulfil something really big for me with the choice to become totally independent again (CH54).

Summarizing the Swiss cases, precarious jobs were not perceived as an ideal work situation, but the individuals had found or integrated some positive aspects they see in their work and based their assessment on that. In terms of Paugam (2000), they do not perceive their work as precarious. In contrast to the Swiss cases, the Romanian cases did not have an on-going reflexive discourse about their working situation. Their satisfaction derived mainly from having a paid job and they particularly appreciated stability and continuity. Over and again the Romanian interviewees came back to the negative points of their work: the low level of their salary/earnings and the poor working conditions. 


\section{Mechanisms contributing to the perception of work in precarious jobs}

The role of the household when coping with precarious job. When looking at the perception of precarious job situations in both countries, we observe that work satisfaction differs from case to case, even among people with similar working conditions and wage levels. To further analyse and understand the perception of work as precarious or not, we argue that the household situation might be an important element. Even the economic situation among these households is almost similar, there are both structural and functional differences.

The household structure differs between the two samples that we reached: in Romania, we did not come across one-person households whereas there were such households in Switzerland. These were the same ones that were working in liberal professions. On the one hand, living alone allows for flexibility in terms of work hours and work place (Hughes 2013). For example, the actor was free to go working abroad in a theatre project for a couple of years and then return to Switzerland thereafter. The photographer mentioned that she had no (care) responsibility for others, which reduced her financial concerns about the future:

I don't have to leave anyone anything, so I don't need life insurance (CH54).

On the other hand, living alone allows for no buffering of financial difficulties and no moral support by other household members. The interviewees did not mention this directly, but the journalist talked about her difficulties bearing the pressure of the job:

I know that I don't have the same resistance to stress any more [...] I have been taking antidepressants for 15 years... ahm, I've been smoking joints since I was 18, euh, 16 years old ( $\mathrm{CH} 4)$.

Buffering within the household. In Romania, the family structure was able to buffer precarious work either economically, by allowing for temporal flexibility or for stability. Living with parents or even with grandparents seemed to have a positive impact on appreciating and accepting a precarious work situation. Three households in the Romanian sample were 
multigenerational (three generations), seven were nuclear families with children (be they of adult age or younger) and the other four were couples.

The presence of young children in a family makes a flexible job desirable for mothers (Davis et al. 2008; Duncan and Irwin 2004), even if the salary is lower and therefore is at risk for becoming a precarious job. The three Romanian women working in flexible jobs with low wages have young children. One of them was a bartender, a single young mother, who was responsible for her 10 -year-old child. She had a teenage pregnancy, never married, with the father paying child alimony sporadically. She earned the minimum wage and completed her salary with tips:

(...) not too much... ... the bar is not top-quality (RO_12).

However, she appreciated the flexible working schedule. She worked shifts; sometimes she was obliged to work at night or on weekends. She received help from her parents and one of her grandparents allowed her to use an apartment free of rent.

Another woman who had a very young child decided to work in an under-qualified job in order to have enough time for her daughter:

My job is from 9 to 5, but they let me adapt the schedule to my child.... I start at 8 and I leave at 3 and I work another hour at home. I work from 8-8:30 onwards in the evening after she goes to sleep. I am very happy from this point of view, I sometimes feel limited but it is a stable job and as long as I have a very young child? ... I have to accept it (RO_06).

In all the RO cases of young women having children, the extended family was the buffer that compensates for the financial burden.

The man who changed career from sales manager to masseur also required the support of his extended family. His wife's aunt borrowed the money for his training courses; his retired father who lived with him contributed to housing expenses. His idea to change careers came at a very difficult moment as his wife had just accepted a new job working in manicure without a contract. Both had tertiary education. The wife was an agronomical engineer and was never able to work in her specialty and thus accepted jobs under her qualifications. 
Even when not living together, parents living in the rural area sent vegetables, fruit, or preserved food products. These were important contributions and this support corresponds to traditional interaction in Romanian families. As the socialist industrialization (between 1975 and 1989) had led to a massive migration from rural to urban areas, a majority of families living in cities still have close relatives in rural areas. Interestingly, after 1990 many households returned to rural areas (Duma et al. 2005; Preoteasa 2015). In the period of transition to the market economy, privatization of the major public industrial companies led to massive layoffs and people coped by returning to their place of origin in the rural area.

Among the Swiss cases of households composed of a partner with or without children, we found household situations buffering risks and negative consequences of precarious work as well. In some cases, the partner had a permanent job with a stable income; in three other cases, the partner's old age pension or the interviewee's father alleviated financial difficulties.

The Swiss sample data suggests that the household situation in parallel with a good social network could be part of the explanation for the positive interpretation of precarious work. This seemed to be the case for the two women working on call. It also seems a plausible explanation for the hairdresser: she was actually not obliged to have a stable income and had the possibility to do professional training thanks to the stable and sufficient financial support of her partner. In comparison to her former situation as a housewife, her precarious work situation (informal work) seemed an improvement to her. Moreover, as the current situation was considered to be transitory, her employment prospects seemed better to her when having completed her professional training. Finally, household income was relevant for the taxi driver. Despite his irregular income, thanks to his willingness to have long working days and to his wife's regular income, the couple earns an income that is more than $80 \%$ of the minimum wage. They've even managed to move out of the welfare position of precarious prosperity.

Cumulating risks and insecurities. Precarious work led quite a few households to accumulate risks and insecurities. This was a frequent 
situation for Romanian families with only one source of income. A singleearner family is at an increased risk of poverty. This may be the reason why the individual work situation was evaluated negatively. Unemployment is also an important source of risk for the household, in particular when the partner has a precarious job with an insecure contract or very low wage. The three households in Romania with at least one member unemployed were strongly affected by this situation. Moreover, the chances of employment were considered to decrease considerably when a person is older than 45 years. This was the case in two interviewed households where the man was older than 45 years of age:

You are dismissed when you are 53 years old. ... If you go anywhere to find a job ... they ask how old, you are. ... if you tell them 53 then they tell you: we will contact you, leave us a phone number (RO_02).

A telling example of the consequences of a precarious job with a standard contract was the case of a Romanian household. The man had a job as stocker. He received his wage with long delays (of many months). His wife became unemployed a few weeks before the interview. She was forced to accept a job with very difficult conditions to compensate for the delays of her husband's wage. To make ends meet, they borrowed money from the daughter's high school scholarship.

In Switzerland, examples where risk accumulated due to precarious jobs were found among cleaners with temporary contracts. In one case the cleaner was living with her second husband and her daughter from a first partner. As a low-skilled worker in structural engineering, the cleaner's husband had periods of work alternating with periods of unemployment. He declared that he was suffering from a psychological burn-out at the moment of the interview. Her adult daughter was living without a residence permit and was working illegally as a hairdresser. The cleaner herself had been without a residence permit for several years before marriage and worked as a nanny with irregular salary and risked being deported. In the second case, the cleaner lived together with her father, mother, and brother. The father's income from early retirement and the mother's income as a 
cleaner were stable, yet insufficient to pay for the household's needs. The cleaner and her brother (both in adult age) were presently employed in lowskilled temporary work.

In the households where the partner had also a precarious job, the situation differed according to whether the household income was perceived to be sufficient over time. The partner of the teacher interviewed was a selfemployed art therapist and sales-representative. The presence of dependent children in the Swiss households seemed important with regards to the meaning of precarious work in households of precarious prosperity. Women with children had lower education, more expenditures and increased difficulties to find work-life balance.

\section{Precarious jobs as a response to structural opportunities}

In Romania, despite irregular payments, there were positive aspects related to the stability of a job that compensated for economic insecurity. The instability of the labour market in Romania, due to deindustrialization, and recently to the economic crises, led to occupational struggle and sometimes forced occupational mobility in order to obtain a standard job (Eurofound 2012). Stability was preferred despite precariousness in particular in terms of low income and identity influences:

My job is stable, my husband's also ... he works in a public company. But we have to accept many things, let go of our pride, and I feel limited (RO_06).

A special situation was that of a woman who was forced to abandon her job after having given birth to her disabled child. The lack of services and alternative solutions led her to become the (paid) personal assistant of her son. She appreciated the chance to care for her child, and accepted her situation as the only one possible. In her account, everything revolved around her son's disability and she did not even mention her professional career:

I stayed at home with him, receiving the minimum wage, minimum not medium. And we thanked God that my husband had a job, he was 
always at work and now it happened? ... He lost his job. And I could stay to take care of our son. I was pleased with the 600 Lei salary (RO11).

She is satisfied having at least the chance to care for her disabled son considering the absence of better job opportunities and specialized child care services.

So, no, I did not have anybody to stay with my child; who could take care of a child with problems? And I could not find a job so well paid that I could afford to pay someone a salary to stay with my child (RO_11).

In Switzerland, the perception of a precarious job with regards to structural opportunities was related to the phase of life, the awareness of possible state support (unemployment benefits, social assistance and old age pension), and future perspectives. For some respondents, the precarious job represented a deterioration in career, for others an improvement. Immigrant background (Lewis et al. 2015), as in the case of the taxi driver and the hairdresser, was not very favourable. The taxi driver came to Switzerland as a political refugee. It was impossible for him to find a job in journalism, which was his major in Switzerland. Despite disadvantageous conditions, he made use of all the opportunities he was offered and trained to become a taxi driver. The hairdresser had not obtained any professional education in her country of origin and had two small children after arriving in Switzerland. The opportunity to participate in professional education and work informally for some hours per week provided her with new perspectives for the future. She considered her precarious job as transitory.

\section{Concluding remarks}

Previous research on work situation considered precarious jobs as an essential trigger for precarity. This holds true even when both employment conditions and the meaning of work for the individuals are considered (Paugam 2000). Our contribution expands this perspective in that precarious 
jobs are embedded into the general situation of the household and larger societal context. It takes into account the role of the household's resources and constraints when analysing the individual experience of a precarious job. We focused on households whose welfare position lies in between poverty and secure prosperity. Our findings shed a different light on precarious jobs; they reveal negative and positive aspects or ambivalence when people describe their satisfaction with their work and when they evaluate their working conditions. The subjective perspective of precarious work is complex. Several factors influence this perspective: the oftenmentioned utilitarian aspects of work either for the individual or for their household, the individual satisfaction with the working conditions or wage level, and the opportunity to achieve personal self-esteem or construct one's identity. When comparing two different countries (in terms of standard of living, culture, historical path, or structural opportunities) we find common patterns for the meaning of precarious jobs to the interviewees. Many interviewees chose precarious jobs as a strategy to avoid slipping into (persistent) poverty, a threat that many of the households faced. Households appreciated precarious jobs that functioned as a means to maintain the present socioeconomic status, especially if their household was able to buffer further risks. Job stability, more than other aspects, was the main issue for the Romanian interviewees; this evaluation is a direct result of the specific local labour market opportunities. In Switzerland, this appreciative attitude towards precarious work occurred specifically among the migrants who had a structurally limited access to the primary labour market. In contrast to the migrants, interviewees with creative/liberal professions chose 'to live to work' pursuing a profession and an identity they wanted at the cost of a lower income and a poorer standard of living and maybe even at the cost of a partnership and family (as they were one-person households). Such situations were possible when individuals with precarious jobs had no care responsibility or were living alone. Individualization of working life (Doherty 2009), possible in more affluent countries, was more present in Swiss situations where work is more strongly related to social identity, 
vocation, and profession. Despite low work income, work satisfaction was intrinsic. Furthermore, the Swiss structural opportunities provided by the labour market and welfare system offered a higher freedom of work decision. At the same time, in Romania the situation might best be described by 'work to live': at any age, in order to avoid slipping into poverty, people end up in precarious jobs or underemployed and generally set intrinsic work motivation aside. The main social support in Romania is provided by extended family, by intra and intergenerational support while the state offered more residual help.

Considering the household role in work decisions and work perceptions we identified two important roles of the household: as buffer for a precarious work situation and as support in coping with precariousness or the opposite, a risk factor when the other members' situation is uncertain.

\section{Acknowledgements}

The author is grateful to the Eliza Markley for her valuable comments that improved the manuscript.

This work was supported by the Swiss Enlargement Contribution in the framework of the Romanian-Swiss Research Programme, grant no. IZERZO_141975.

\section{References}

Allen, Tammy D., Ryan C. Johnson, Kaitlin M. Kiburz, and Kristen M. Shockley. 2013. "Work-Family Conflict and Flexible Work Arrangements: Deconstructing Flexibility." Personnel Psychology 66 (2): 345-376. doi:10.1111/peps.12012.

Ardichvili, Alexander and Peter K. Kuchinke. 2009. "International perspectives on the meanings of work and working: current research and theory." Advances in Developing Human Resources 11 (2): 155-167.

Brown, Steven P. and Robert A. Peterson. 1994. "The effect of effort on sales performance and job satisfaction." Journal of Marketing 58(2): 70-80 
Budowski, Monica, Robin Tillmann, Wiebke Keim, and Michèle Amacker. 2010. "Conceptualizing 'precarious Prosperity': Empirical and Theoretical Elements for Debate." International Journal of Comparative Sociology 51 (4): 268-288. doi:10.1177/0020715210368840.

Budowski, Monica, Sebastian Schief, and Rebekka Sieber. 2016. "Precariousness and Quality of Life-a Qualitative Perspective on Quality of Life of Households in Precarious Prosperity in Switzerland and Spain." Applied Research in Quality of Life 11(4): 1035-1058. doi:10.1007/s11482-015-9418-7.

Coontz, Stephanie. 2005. Marriage, a History How Love Conquered Marriage. London: Penguin Books.

Craig, Lyn, Abigail Powell, and Natasha Cortis. 2012. "Self-employment, work-family time and the gender division of labour." Work Employment and Society 26 (12): 716-734.

Davis, Kelly D., W. Benjamin Goodman, Amy E. Pirretti, and David M. Almeida. 2008. "Nonstandard Work Schedules, Perceived Family Well-Being, and Daily Stressors." Journal of Marriage and Family 70 (4): 991-1003. doi:10.1111/j.1741-3737.2008.00541.x.

Dewilde, Caroline. 2003. "A life-course perspective on social exclusion and poverty." The British Journal of Sociology 54 (1): 109-128.

Dewilde, Caroline and Bram Lancee. 2013. "Income inequality and access to housing in Europe." European Sociological Review 29 (6): 1189-1200.

Diekmann, Andreas, and Ben Jann. 2005. "The erosion of regular work: an analysis of the structural changes in the Swiss and German labour markets." In Contemporary Switzerland. Revisiting the Special Case, edited by Hanspeter Kriesi, Peter Farago, Martin Kohli, and Milad Zarin-Nejadan, 190-217. New York: Palgrave Macmillan.

Doherty, Michael. 2009. "When the working day is through: the end of work as identity?" Work, Employment \& Society 23 (1): 84-101.

Duma, Viorica, Maria Molnar, Filofteia Panduru and Daniel Verger. 2005. "Roumanie: une agriculture de survie, après l'industrialisation force." Economie et statistique 383 (1): 193-217.

Duncan, Simon, and Sarah Irwin. 2004. "The social patterning of values and rationalities: mothers' choices in combining caring and employment." Social Policy and Society 3 (4): 391-399.

Ecoplan. 2010. "Die Entwicklung Arbeitsverhältnisse in der Schweiz Ecoplan" Forschung 32: 1-13, 24-35.

Eurofound. 2007. First European quality of life survey: quality of work and life satisfaction. European Foundation for the Improvement of Living and Working Conditions. 
Eurofound. 2012. Eurofound Yearbook 2011: Living and working in Europe. Luxembourg: Office for Official Publications of the European Communities.

Eurostat. 2015. Employment and economic activity branches, http://ec.europa.eu/eurostat/data/database?node_code=med_ps4 1.

Fenton, Steve, and Esther Dermott. 2006. "Fragmented careers? Winners and losers in young adult labour markets." Work, Employment \& Society 20 (2): 205-221.

Foster, Karen. 2012. "Work, narrative identity and social affiliation." Work, Employment \& Society 26 (6): 935-950.

Gefken, Andreas, Franziska Stockem, and Petra Böhnke. 2015. “Subjektive Umgangsformen mit prekärer Erwerbsarbeit - Zwischen Orientierung an und Ablösung von der Normalarbeitsgesellschaft." Berliner Journal für Soziologie 25 (1-2): 111-31. doi:10.1007/s11609015-0276-9.

Greenhaus, Jeffrey, and Gary N. Powell. 2006. "Is the opposite of positive negative?: Untangling the complex relationship between workfamily enrichment and conflict Is the opposite of positive negative? Untangling the complex relationship between work-family enrichment and conflict." Career Development International 11(7): 650659.

Greenhaus, Jeffrey H., and Gary N. Powell. 2012. "The Family-Relatedness of Work Decisions: A Framework and Agenda for Theory and Research." Journal of Vocational Behavior 80 (2): 246-55. doi:10.1016/j.jvb.2011.12.007.

Greenhaus, Jeffrey, and Sharon Foley. 2007. "The intersection of work and family lives." In Handbook of Career Studies, edited by Hugh Gunz and Maury Peiperl, 131-152. Thousand Oaks, California: Sage Publications.

Hanappi, Doris, Valerie-Anne Ryser, Laura Bernardi, and Jean-Marie Le Goff. 2012. "Precarious Work and the Fertility Intention-Behavior Link: An Analysis Based on the Swiss Household Panel Data." LIVES Working Papers 2012 (17): 1-27. doi:10.12682/lives.22961658.2012.17.

Hanappi Doris, Valerie-Ann Ryser, and Laura Bernardi. 2014. "Coping strategies under uncertain, precarious employment conditions in Switzerland." Families and societies 2014 (12): 1-30.

De Hauw, Sara, and Jeff Greenhaus. 2014. "Building a Sustainable Career: The Role of Work-Home Balance in Career Decision Making." 
Academy of Management Proceedings 2014 (1): 13367-13367. doi:10.5465/AMBPP.2014.13367abstract.

Hughes, Jody. 2013. "A logical response to the demands of the labour market? Young people living alone in Australia." Current Sociology 61 (7): 966-983.

Kalleberg, Arne L. 2009. "Precarious work, insecure workers: employment relations in transition." American Sociological Review 74(1): 1-22.

Kraemer, Klaus. 2008. "Integration und Desintegration. Wie aktuell sind diese soziologischen Schlüsselbegriffe noch für eine moderne Gesellschaftsanalyse?" Swiss Journal of Sociology 34 (1): 37-53.

Lebert, Florence, and Marieke Voorpostel. 2016. "Turnover as a Strategy to Escape Job Insecurity: The Role of Family Determinants in DualEarner Couples." Journal of Family and Economic Issues 37 (3): 407-21. doi:10.1007/s10834-016-9498-z.

Leschke, Janine. 2009. "The segmentation potential of non-standard employment: A four-country comparison of mobility patterns." International Journal of Manpower 30 (7): 692-715.

Lewis, Hannah, Peter Dwyer, Stuart Hodkinson, and Louise Waite. 2015. "Hyper-precarious lives: Migrants, work and forced labour in the Global North." Progress in Human Geography 39 (5): 580 - 600.

Lloyd, Anthony. 2012. "Working to live, not living to work: Work, leisure and youth identity among call centre workers in North East England." Current Sociology 60 (5): 619-635.

Marcus-Newhall, Amy, Diane F. Halpern, and Sherylle J. Tan. 2008. Changing Realities of Work and Family. Claremont Applied Social Psychology Series. Malden, MA; Oxford: Wiley-Blackwell Pub.

Nilsen, Ann. 2012. “Work, Life Course, and Gender." European Societies 14 (1): 113-134.

OECD. 2016. Minimum relative to average wages of full-time workers, https://stats.oecd.org/Index.aspx?DataSetCode=MIN2AVE\#.

Paugam, Serge. 2007. Le salarié de la précarité: les nouvelles formes de l'intégration professionnelle. Paris: PUF.

Perrone, Kristin M., L. Kay Webb, and Z. Vance Jackson. 2007. "Relationships Between Parental Attachment, Work and Family Roles, and Life Satisfaction." The Career Development Quarterly 55 (3): 237-48. doi:10.1002/j.2161-0045.2007.tb00080.x.

Powell, Gary N., and Jeffrey Greenhaus. 2010. "Sex, Gender, and the Workto-Family Interface: Exploring Negative and Positive Interdependencies Sex, Gender, and the Work-to-Family Interface." Academy of Management Journal 53 (3): 513-534. 
Precupețu, Iuliana, Ana Maria Preoteasa, and Ionela Vlase. 2015. Beyond Poverty in Romania: An Analysis of Household-Level Factors of Poverty and Precarious Prosperity. Sociologia 3(13): 253-271.

Preoteasa, Ana Maria. 2015. "Munca precara, solutie pentru populatia vulnerabilă din mediul rural." Calitatea Vieții XXVI (1): 36-59.

Procoli, Angela. 2004. Workers and narratives of survival in Europe. Albany, NY: State University of New York Press.

Przeworski, Adam, and Henry Teune. 1970. Logic of Comparative Social Inquiry. Malabar, Florida: Krieger Publishing Company.

Ragin, Charles. 1987. The Comparative Method: Moving Beyond Qualitative and Quantitative Strategies. Berkeley: University of California Press.

Rihoux, Benoit, and Charles Ragin. 2009. Configurational Comparative Methods Qualitative Comparative Analysis (QCA) and Related Techniques. Thousand Oaks California: SAGE Publications.

Saldana, Johnny. 2009. Fundamentals of qualitative research. Understanding qualitative research. New York: Oxford University Press.

Sandu, Dumitru. 2011. "Social disparities in the regional development and policies of Romania." International Review of Social Research 1 (1): 130.

Standing, Guy. 2011. The Precariat. The New Dangerous Class. London: Bloomsbury Academic.

Sverke, Magnus, Johnny Hellgren, and Katharina Näswall. 2002. "No security: a meta-analysis and review of job insecurity and its consequences." Journal of Occupational Health Psychology 7 (3): 242264.

Townsend, Peter. 2010. "The meaning of poverty" 1962. The British Journal of Sociology 61 (Suppl. 1): 85-102.

Umney, Charles, and Lefteris Kretsos. 2015. "'That's the Experience': Passion, Work Precarity, and Life Transitions Among London Jazz Musicians." Work and Occupations 42 (3) 313-334

Vosko, Leah F. 2003. "Precarious employment in Canada: taking stock, taking action." Just Labour 3 (Fall): 1-5.

Vosko, Leah F. 2010. Managing the margins gender, Citizenship and the International Regulation of Precarious Employment. New York: Oxford University Press.

Wallace, Claire, Florian Pichler, and Bernadette C. Hayes. 2007. First European Quality of Life Survey: Quality of work and life satisfaction, Luxembourg: Office for Official Publications of the European Communities.

Walker Philipp and Michael Marti. 2010. “L'évolution des emplois atypiques 
et précaires en Suisse." La Vie Economique. 55-58;

Witte, Hans D. 1999. "Job insecurity and psychological well-being: review of the literature and exploration of some unresolved issues." European Journal of Work E Organizational Psychology 8 (2): 155-177.

Zeytinoglu, Isik U., and Gordon Cooke. 2008. "Non-standard employment and promotions: a within genders analysis." Journal of Industrial Relations 50 (2): 319-337. 